УДК 33.336.1:352

Шульженко I.B., к.е.н., доцент

Лупинос Р.С., магістрант спеціальності «Менеджмент»

Полтавська державна аграрна академія

\title{
ОСОБЛИВОСТІ УПРАВЛІННЯ КОНФЛІКТАМИ В СУЧАСНІЙ ОРГАНІЗАЦЇ̈
}

У статті досліджено причини виникнення конфліктів, особливості управління ними, виявлення та застосування яких сприятиме підвищенню ефективності управління та функціонування сучасної організації.

Актуальність обраної теми полягає в тому, що наявність конфліктів неминуча в умовах функціонування будь-якій організації, тому виявлення особливостей управління ними та причин їх виникнення, є одним із важливих напрямів управління сучасною організацією.

Ефективне управління конфліктами полягає у здатності менеджера знаходити оптимальні шляхи їх вирішення, які можуть бути як функціональними, так і дисфункціональними та будуть впливати на діяльність організації у довгостроковій перспективі.

Також необхідно наголосити на особливостях управління конфліктами, які спираються на концепцію корпоративної соціальної відповідальності та важливості ролі керівника в управлінні конфліктами.

Ключові слова: конфлікт, організаційний конфлікт, управління конфліктами, причини конфлікту, корпоративна соціальна відповідальність.

Shulzhenko I., Lupinos R.

\section{FEATURES OF CONFLICT MANAGEMENT IN MODERN ORGANIZATION}

The article investigates the causes of conflicts, peculiarities of their management, the identification and application of which will help to improve the efficiency of management and functioning of the modern organization.

The relevance of the chosen topic is that the presence of conflicts is inevitable in the conditions of functioning of any organization, so identifying the peculiarities of managing them and the causes of their occurrence is one of the important areas of management of a modern organization.

Effective conflict management is the ability of the manager to find the best ways to resolve them, which can be both functional and dysfunctional and will affect the organization's performance in the long run.

It is also necessary to emphasize the features of conflict management, which are based on the concept of corporate social responsibility and the importance of the role of the leader in conflict management.

Keywords: conflict, organizational conflict, conflict management, causes of conflict, corporate social responsibility.

Шульженко И.В., Лупинос Р.С.

\section{ОСОБЕННОСТИ УПРАВЛЕНИЯ КОНФЛИКТАМИ В СОВРЕМЕННОЙ ОРГАНІЗАЦИИ}

В статье исследованы причины возникновения конфликтов, особенности управления ими, выявление и применение которых будет способствовать повышению эффективности управления и функционирования современной организации.

Актуальность выбранной темы состоит в том, что наличие конфликтов неизбежно в деятельности любой организации, поэтому выявление особенностей управления ими и причин их возникновения, является одним из важных направлений управления современной организацией. Эффективное управление конфликтами заключается в способности менеджера находить оптимальные пути их решения, которые могут быть как функциональными, так и дисфункциональными и влиять на деятельность организации в долгосрочной перспективе.

Также необходимо подчеркнуть особенностях управления конфликтами, которые опираются на концепцию корпоративной социальной ответственности и важности роли руководителя в управлении конфликтами.

Ключевые слова: конфликт, организационный конфликт, управление конфликтами, причины конфликта, корпоративная социальная ответственность. 
Постановка проблеми у загальному вигляді і її 3 важливими науковими та практичними завданнями. Здійснення ефективного управління організаційними конфліктами, виявлення їхніх причин та пошук шляхів їх вирішення, зокрема згідно принципів корпоративної соціальної відповідальності є вкрай важливою проблемою, пов'язаною з ефективним управлінням сучасною організацією.

Аналіз останніх досліджень, у яких започатковано вирішення проблеми. Теоретичним та практичним аспектам аналізу причин виникнення конфліктів в організаціях, управління ними в сучасних умовах господарювання присвячена значна кількість робіт учених, таких як Акофф Р., Гудзинський О.Д., Дойч М. [3], Смільянов С.М. [2], Крис О.Й., Новіков Н., Подольчак Н. Ю. [6] та ін. Однак при цьому недостатньо уваги приділялося висвітленню особливостей управління ними, зокрема шляхом використання концепції соціальної відповідальності.

Цілі статті. Метою статті $є$ дослідження причин виникнення конфліктів та особливостей управління ними в сучасній організації; удосконалення методів управління конфліктами, зокрема базуючись на принципах ділової етики, зокрема на концепції корпоративної соціальної відповідальності.

Виклад основного матеріалу дослідження 3 повним обгрунтуванням отриманих наукових результатів. В процесі функціонування будь-якої сучасної організації ймовірність виникнення розбіжностей у поглядах на ту або іншу подію або явище $\epsilon$ доволі високою. Все тому що в центрі будь-якого процесу знаходиться людина. Отже, взаємодія людей в процесі їхньої діяльності, призводить в явній або прихованій формі до зіткнення їх інтересів. Конфлікт народжується на грунті щоденних розбіжностей думок, поглядів, потреб, бажань, інтересів, стилів роботи. Через ці розбіжності виникають протистояння і суперництво, що в свою чергу порушує особистий або між особистий спокій, емоційну рівновагу і призводить до порушення сталих відносин у колективі та виникнення кризової ситуації.

При спілкуванні з колегами, керівництвом, підлеглими, партнерами по бізнесу або клієнтами виникає протилежність поглядів, думок, що в свою чергу призводить до конфліктів або суперечок між членами групи, групами в цілому. Кожна із сторін вважає свою позицію вірною і намагається їі відстоювати. Тобто, організаційний конфлікт впливає як на поведінку членів колективу, що стали учасниками конфлікту, так і на діяльність організації в цілому [1].

Форми конфліктів в організації можуть різнитися залежно від певних обставин. Для ефективного управління конфліктами незалежно від того яку форму вони приймають, дуже важливо проаналізувати, оцінити і зрозуміти їхні причини.

Тобто, одним із перших завдань при побудові схеми управління конфліктами загалом чи окремим конфліктом зокрема $є$ виявлення причин, що до них призвели. Зрозуміло, що причин конфліктів існує безліч.

Конфлікт може бути дисфункціональним, який знижує продуктивність праці, що в свою чергу може призвести до зниження мотивації співробітників, негативно впливати на ефективність організації та групового співробітництва.

Функціональний або конструктивний конфлікт навпаки, може бути дуже корисним i вести до підвищення продуктивності праці учасників трудового колективу та організації в цілому [2].

Треба зазначити, що конфлікт - одна з найбільш поширених форм організаційної взаємодії. Розвиток та нарощування потенціалу організації безпосередньо пов'язане із виникненням конфліктних ситуацій, які виникають при цьому. Разом 3 тим, конструктивні конфлікти $є$ рушійним факторм розвитку організації. В багатьох випадках, керівництво застосовує тактику уникнення конфліктних ситуацій в колективі будь-яким чином, оскільки в свідомості більшості працівників конфлікт призводить до погіршення взаємостосунків, втрати взаєморозуміння та довіри, зниженню працездатності тощо. Тому завданням керівництва можна вважати зосередження на запобіганні та професійному управлінні деструктивними конфліктами. Майстерність 
управління конфліктом заснована на глибоких знаннях керівником природи, ознак, технології та особливостей відповідного інструментарію.

Варто зазначити, що успішне функціонування організації неможливе без ефективного управління нею. Складовою частиною такого управління є вдале керування конфліктами, яке може сприяти досягненню цілей управління організацією загалом. Основною метою управління конфліктами $є$ запобігання виникнення деструктивних конфліктів і сприяння вирішенню конструктивних.

Для того, щоб конструктивно управляти конфліктами, керівнику необхідно: визначити вид конфлікту, його причини, особливості, а потім застосувати необхідний для даного конфлікту спосіб вирішення. Конструктивне управління конфліктом $\epsilon$ довготривалим, складним процесом, який веде до вирішення проблем, що виникли на певному етапі розвитку, на основі вироблення спільної програми дій по урегулюванню ситуації [3, с. 210].

Конструктивне управління конфліктами починається з їх передбачення. Грамотний керівник повинен постійно працювати над виявленням та усуненням причин, що призводять до організаційних конфліктів. Спроби уникнути вирішення проблем призводить лише до їхнього поглиблення та погіршення соціально-психологічного клімату у колективі, що в підсумку може призвести до зниження продуктивності праці та кадрових втрат.

Далі детальніше розглянемо основні причини конфліктів в організації. Причини виникнення організаційних конфліктів можуть різнитися в залежності від певних обставин зовнішнього та внутрішнього характеру.

Причинами організаційного конфлікту можна вважати певні події та ситуації, що викликали зіткнення поглядів на сутність предмету конфлікту, передують йому та викликають його за певних сприятливих умов діяльності співробітників. При виявленні причин конфліктів можна дослідити джерела їх виникнення і визначити динаміку перебігу.

Деякі науковці виділяють наступні причини конфліктів [4, 5]:

- розподіл ресурсів між підрозділами організації, який може викликати у працівників відчуття несправедливості;

- взаємозалежність завдань, що існує в організаціях, де один працівник або група залежить від виконання завдань іншої особи або групи;

- різниця в цілях, яка викликає незадоволеність діями іншої сторони;

- різниця в уявленнях і цінностях, яка виникає у разі неспівпадінь думок учасників конфліктної взаємодії;

- різниця в поведінці і життєвому досвіді спирається на відмінних один від одного життєвому досвіді, освіті, виробничому стажі та віці;

- незадовільні комунікації можуть сприяти розвитку організаційного конфлікту через відсутність достовірної інформації.

Поряд із загальними причинами організаційних конфліктів, у науковій літературі досліджуються і певні конкретні підходи, до яких відносять [6]:

-соціальні розбіжності;

-проблеми розподільних відносин;

- рольові суперечності;

- розділення провини, відповідальності;

-лідерство.

Всі вищезазначені причини виникнення конфліктів, дозволяють обрати конкретні методи, шляхи запобігання їм та конструктивне їх вирішення. Без знання цих рушійних сил виникнення конфліктів важко на них ефективно впливати та регулювати.

Далі, базуючись на основних причинах організаційних конфліктів, спробуємо сформулювати конкретні пропозиції щодо удосконалення управління ними. 
Так, науковцями розроблено та досліджено певні етичні норми та правила для попередження дисфункціональних конфліктів та врегулювання взаємин у колективі. Це різноманіття пояснюється можливістю вільного вибору кожним із учасників конфліктної взаємодії тих чи інших моральних цінностей.

Одним із проявів цього різноманіття етичних правил і норм і їх високої ролі є ділова етика.

Ділова етика у менеджменті пов'язана з внутрішніми цінностями організації, які є частиною корпоративної культури і впливають на соціальну допустимість тієї або іншої діяльності у рамках зовнішнього середовища, тому кожна організація повинна накладати на себе певні обмеження.

Етична відповідальна діяльність допомагає покращувати привабливість організації при пошуку кваліфікованих працівників, підтримувати добру волю членів організації й підвищувати цінність і надійність організації, забезпечувати послідовний і постійний розвиток організації. Етична відповідальна діяльність впливає не тільки на людей i зацікавлені групи а також на інтереси й довгострокову рентабельну діяльність організації. Тобто, інакше кажучи, етична відповідальна діяльність допомагає краще управляти організацією[7,8].

Треба зазначити, що в сучасних умовах все більшої ваги набирає вбудова у стратегію організації принципів корпоративної соціальної відповідальності, використання якої підвищує довіру до дій керівництва та сприяє підвищенню ефективності управління конфліктами.

Принципи корпоративної соціальної відповідальності визначають основні положення діяльності сучасної організації з реалізації основних їі положень.

Науковцями виділяють наступні принципи корпоративної соціальної відповідальності:

-відкритість (прозорість, публічність, достовірність, діалог);

-системність (спрямованість, єдність у часі, єдність у просторі, регулярність, інтегрованість);

-значущість (актуальність, масштабність, ефективність);

-недопущення конфліктів.

Соціальна активність організації виражається у проведенні різноманітних соціальних програм як внутрішньої, так і зовнішньої спрямованості. Відмінними особливостями програм соціальної активності $\epsilon$ добровільність їх проведення, системний характер і пов'язаність з місією та стратегією розвитку. [9,с.183].

Традиційно в рамках внутрішньої корпоративної соціальної відповідальності найбільша увага приділяється розвитку відносин із працівниками підприємства, їх розвитку та соціальній захищеності. Подібний підхід виступає вже не просто як турбота про колектив, а розглядається як необхідна умова виживання і розвитку організації в довгостроковій перспективі і зокрема у профілактиці та попередженні організаційних конфліктів.

Важливою складовою управління конфліктами в сучасній організації є стратегія поведінки та роль керівника в цьому процесі. Він повинен володіти певними якостями, як особистими, так і професійними, бути людиною високої культури поведінки, яка володіє знаннями і навичками в сфері ділових відносин та додержується ефективного стилю керівництва.

Таким чином, особистість керівника можна вважати одним з вирішальних факторів ефективного управління конфліктами в організації.

Треба зазначити, що існує безліч прийомів вирішення конфліктів, користуючись якими керівник грамотно буде регулювати і вирішувати конфліктні ситуації таким чином, що це буде підвищувати як його авторитет, так і підвищувати ефективність функціонування всієї організації. 
Спираючись на дослідження науковців та власні спостереження, сформулюємо фактори, які впливають на конструктивне управління конфліктами [10,с.318] :

- емоційний стан опонентів, відносини всередині певної групи;

- своєчасність вирішення конфлікту, робота 3 ним при виявленні його перших ознак;

- достатньо високий рівень загальної культури учасників конфлікту;

- єдність цілей;

- стиль поведінки у конкретній ситуації;

- згода опонентів відносно компромісного рішення;

- наявність певного досвіду у вирішенні даної проблеми;

- гарні взаємостосунки між сторонами до початку конфлікту.

\section{Висновки.}

Таким чином, можна констатувати, що мета дослідження досягнута, а саме доведено, що основною метою управління конфліктами $є$ попередження деструктивних конфліктів та адекватне вирішення конструктивних або функціональних конфліктів.

Конфліктні ситуації можуть бути точками зростання та розвитку організації, створити передумови для формування в ній нових міжособових відносин. На нашу думку, для реалізації цієї важливої функції конфліктів, необхідно дотримання наступних умов:

По-перше, зміна відношення до конструктивних конфліктів, формування позитивного відношення до них, уміння бачити в них конструктивний початок;

По-друге, формування умінь аналізувати конфліктні ситуації, управляти ними, знаходити нові шляхи їх вирішення, зокрема такі як застосування концепції корпоративної соціальної відповідальності.

\section{Список бібліографічного опису:}

1. Микитюк O.А., Конфлікт в організації. Сучасні проблеми управління людськими ресурсами. URL: https:/cyberleninka.ru/ article/v/ konflikty- v-organizatsii-2 83 (дата звернення: 03.07.2019).

2.Ємільянов С.M. Управління конфліктами в організації: підручник для вищих навчальних закладів URL: http://studentam. net.ua/ content/ view/4095/86/ (дата звернення: 22.06.2019).

3.Дойч М. Вирішення конфлікту (Конструктивні та деструктивні процеси). Соиіально-політичний журнал. 1997. №1. С. $202-212$

4. Роль менеджера в процесі управління конфліктами. URL: http://buklib.net /component/ option,com_ jbook/task,view/ Itemid,36/catid,136/id,4195/(дата звернення: 03.09.2018).

5. Скородумова Э. З. Конструктивное управление конфликтами в организации как психологический феномен. Научно-методический электронный журнал «Конщепт». 2015. T. 10. C. 261-265. URL: http://e-koncept.ru/2015/95096.htm. (дата звернення: 01.08.2019).

6. Ковальчук Г. Р., Подольчак Н. Ю. Місце та види управлінських конфліктів в системі менеджменту підприємства. Вісник Національного університету - Львівська політехніка: - Менеджмент та підприємництво в Україні: Етапи становлення та проблеми розвитку. 2012. №748. С. 88-95.

7. Діловий етикет в менеджменті та в бізнесі. URL: http://stud24.ru/management/dlovij-etiket-v-menedzhment-ta/506567-2057609page1.html (дата звернення: 17.06.2019).

8. Воронкова В.Г., Беліченко А.Г., Мельник В.В., Ажажа М.А. Етика ділового спілкування. Львів:« Магнолія, 2006». 2009. 312 с.

9.Гришова І. Ю. Шабатура Т. С. Соціальні інвестиції як інструмент реалізації соціально оріснтованого бізнесу. Вісник Сумського начіонального аграрного університету. Серія «Економіка і менеджмент». 2014. 4. С. 183-187.

10. Кульчицька А. Г. Роль менеджера в процесі управління конфліктами. Матеріали міжвузівської наук.-практ. конф., присвяченої Дню науки. ЖДТУ, 2012. Т.2. С. 318-319.

\section{References:}

1. Mykytyuk OA, Konflikt v orhanizatsiyi. Suchasni problemy upravlinnya lyuds'kymy resursamy. [Conflict in the organization. Modern problems of human resources management]. [E-Reader Version]. Retrieved from: https: //cyberleninka.ru/article/v/konflikty-v-organizatsii2 83. [in Russian].

2.Emilyanov S.M. Upravlinnya konfliktamy v orhanizatsiyi [ Conflict Management in the Organization]: [E-Reader Version]. Retrieved from: http: // studentam. net.ua/ content / view / 4095/86 / [in Ukrainian]

3.Deutch M. (1997). Vyrishennya konfliktu (Konstruktyvni ta destruktyvni protsesy). [Conflict resolution (Constructive and destructive processes)]. Socio-political journal. 1,202-212. [in Ukrainian].

4. Rol' menedzhera v protsesi upravlinnya konfliktamy. [The role of the manager in the process of conflict management]. [E-Reader Version]. Retrieved from: http://buklib.net / component / option, com jbook . [in Ukrainian].

5. Skorodumova E. Z. (2015). Konstruktivnoye upravleniye konfliktami v organizatsii kak psikhologicheskiy fenomen [ Constructive management of conflicts in the organization as a psychological phenomenon]. Scientific and methodical electronic magazine "Concept", 10, 261-265. [E-Reader Version]. Retrieved from: http://e-koncept.ru/2015/95096.htm. [in Russian].

6. Kovalchuk G.R., Podolchak N.Yu.(2012). Mistse ta vydy upravlins'kykh konfliktiv v systemi menedzhmentu pidpryyemstva. [Place and types of managerial conflicts in the enterprise management system]. Bulletin of the National university - Lviv polytechnic: - Management and entrepreneurship in Ukraine: Stages of formation and problems of development,748, 88-95. [in Ukrainian]

7. Dilovyy etyket $\mathrm{v}$ menedzhmenti ta $\mathrm{v}$ biznesi. [Business etiquette in management and business].(2011). [E-Reader Version]. Retrieved from: http://stud24.ru/management/dlovij-etiket-v-menedzhment-ta/506567-2057609-page1.html. [in Ukrainian]

8. Voronkova V.G., Belichenko A.G., Melnyk V.V., Azazha M.A. (2009). Etyka dilovoho spilkuvannya. [Ethics of business communication 1. L'viv: "Mahnoliva, 2006», 312. [in Ukrainian]

9. Grishova I. Yu., Shabatura T.S. (2014). Sotsial'ni investytsiyi yak instrument realizatsiyi sotsial'no oriyentovanoho biznesu. [Social investments as a tool for realization of socially oriented business]. Bulletin of Sumy National Agrarian University. Economics and Management Series, 4,183-187. [in Ukrainian]

10. Kulchytska A. (2012). Rol' menedzhera v protsesi upravlinnya konfliktamy [The role of the manager in the process of conflict management]. ZHDTU, T.2, 318-319. [in Ukrainian]

Рецензент д.е.н., професор Махмудов Х.3. 